\title{
Building Shanghai's Dreamworld: Architects and Elite Ballroom Designs of the 1920s and 1930s
}

\author{
Andrew Field \\ Kunshan Duke University, Kunshan, China \\ Email: andrew.field@dukekunshan.edu.cn
}

\begin{abstract}
Using historical records from the period including newspapers and architectural journals, this paper examines seven ballrooms built in Shanghai between the 1920s and 1930s. These ballrooms were all designed by leading architects and reflect their ambitions and visions in creating fantastical spaces for the city's elites to celebrate their status while socializing with other members of high society. Their technological features include sprung dance floors, sophisticated lighting schemes, and other technical wizardry to enhance the experience of dancing and being entertained. One ballroom was in the style of a traditional Chinese palace, highlighting the connection to earlier forms of culture in China. Today most of these ballrooms still exist and many of their original features are still intact, although the dancing has been superseded by other activities such as wedding banquets, conferences, and even the stock exchange.
\end{abstract}

KEYWORDS China entertainment culture, architecture, urban design, Shanghai interwar ballrooms, dancing society

Received May 27, 2019; accepted August 20, 2019.

During the 1920s and 1930s, Shanghai established its identity as a global crossroads and city of nightlife. As the Jazz Age heated up and people took to dancing the foxtrot, Charleston, tango, and rumba in greater numbers, architects from around the world joined in the race to design and build the most luxurious ballrooms in the city ${ }^{1}$. Whether housed in hotels, clubs, or stand-alone buildings, ballrooms were hallmark spaces for the city's leading architects and interior designers to showcase their skills while contributing to the legendary image and reality of Shanghai as a nighttime metropolis of fun, fantasy, and pleasure.

The list of architects who designed elite ballrooms in 1920s-1930s Shanghai reads like a Who's Who of Shanghai-based architects and speaks to the city's role as a global metropolis. They include the Spanish architect Abelardo Lafuente (1871-1931), who designed the Astor House and Majestic Hotel ballrooms; the French architect Paul Veysseyre (1896-1963) and his partner A. Leonard, who created the new French Club or Cercle Sportif Français in the 1920s; the British architect George Leopold 'Tug' Wilson (1880-1967) of the Hong Kong and Shanghai-based firm Palmer and Turner, who conceived the Cathay Hotel and Sassoon House, now known as the Fairmont Peace Hotel; the Austro-Hungarian architect László Hudec (18931958), who crafted the Park Hotel and its Sky Terrace Ballroom; and the Chinese architect S. J. Young (Yang Xiliu) (1899-1978), who rendered both the Paramount Ballroom and the Metropole Gardens Ballroom.

This paper focuses on these seven ballrooms, which were among the city's leading ballrooms from the 'golden age' of the 1920s and 1930s, in order to shine a spotlight on how these architects created a beautiful dancing dreamworld for the city's elite residents and visitors. The ballrooms from that era, along with the buildings in which they were housed, became a celebrated part of the distinctive cultural, intangible, and built heritage of Shanghai as a global crossroads. Today they are still a key facet of the city's identity as the former Paris of the East and the leading jazz-age nightlife metropolis in Asia (Field 2010; Farrer and Field 2015).

Shanghai is still well-known today for its Deco cinemas, ballrooms, and theatres from the 1930s. Ballrooms differed from other entertainment halls in one key aspect: whereas theatres and cinemas offered staged or screened entertainment for guests, ballrooms were 'action environments' which in addition to providing staged entertainment 
also involved the active participation of those who patronized them ${ }^{2}$. We can examine the specific materials, designs, decorations, lighting schemes, technologies, and layouts of these ballrooms in their heyday. Chinese architectural journals from the era showcase the designs of some of these ballrooms, such as the Paramount Ballroom and Metropole Gardens Ballroom. Newspapers are also a fine source of information for learning about the designs of the ballrooms, and how the city's elites used these ballrooms for various purposes. Shanghai's elite communities composed of various nationalities used ballrooms for holding grand balls, festivals, charities, fashion shows, award ceremonies, weddings parties, banquets, and other special events, as well as for regular nighttime fun. These were the stages upon which eliteness in Shanghai was performed in its grandest style. Ballrooms from the early $20^{\text {th }}$ century were grand stages of elite and popular social, cultural, and civic life in an age when social dancing was become a regular and important social activity for elites and for non-elites alike. They embody the aspirations and dreams of a sophisticated and lost age, bookended by the two great wars of the century.

The architectural and design features of interwar Shanghai ballrooms served many purposes and were subject to many changes and developments over time. As Hilary French writes in her study of London ballrooms: 'The history of the ballroom is a history of both the dance and the spaces it occupies and as a history of the design of the interior, rather than the description of the static architecture of the building, it is a history of change; a shifting history of renovations, alterations, additions, and redecorations' (French 2015,43-44). This is certainly true in the case of the ballrooms of Shanghai, which were constantly going through renovations and redecorations in their heyday. James Nott's pioneering work on the history of dance halls in the United Kingdom in the early $20^{\text {th }}$ century also highlights the importance of the design features of these entertainment halls, showing how they created fantastical environments for middle- and workingclass Britons to escape their mundane workaday lives and enter fantasy worlds of fun and pleasure (Nott 2015). As Nott concludes in his article on dance hall architecture from that period: 'Dance halls provided an architecture of optimism, hope and modernity, and their style and function represented a democratisation of pleasure and the emergence of a more liberal social and political culture in Britain' (Nott 2018, 229). This was also true in Shanghai during the 1920s-1930s, and yet ballrooms were also spaces where urban elites set themselves apart from the urban masses (Field 2010; Farrer and Field 2015).
Ballrooms were and still are distinctive spaces for the demarcation and expression of social stratification and wealth differentiation in the modern city. In 1920s-1930s Shanghai, they were generally categorised in terms of class. As with the ballrooms of London and suburban England, the ballrooms of Shanghai usually were large halls dedicated to dancing, which reflected a great effort put into the design elements so that customers could imagine themselves transported to other worlds. In American cities in the same era such as New York, San Francisco and Chicago, dance halls of various types and classes abounded ${ }^{3}$. Many were 'taxi-dance halls' with women hired by the establishment and paid by customers to dance with them. By the 1930s, most of the middle- and low-class ballrooms in Shanghai invariably featured dance hostesses (Cressey 2008 and Mumford 1997). Known in Chinese as wunü, these young women served as dancing partners for male customers. The ballrooms that served as taxi-dance halls tended to be simpler in design and décor, featuring large open spaces for the dancing. Whether they were categorized as high-, middle-, or low-class, all ballrooms in the city shared some fundamental features. In order to facilitate the main activity of dancing, most if not all ballrooms featured live jazz orchestras as well as various staged performances by hired performers. The central feature of the ballroom was invariably the dance floor, and the central activity was male-female-and more rarely, same sexpartnered dancing to the tunes of the live orchestra.

High-class ballrooms were elaborate, luxurious, and expensive in their design and décor, and they were often housed in fancy buildings. They reflected a higher level of investment and close attention to design details. With the notable exception of the Metropole Ballroom discussed later in this paper, they tended not to hire dance hostesses, although that situation changed after the Japanese military invasion and occupation of Greater Shanghai in 1937 and even high-class ballrooms had to hire hostesses in order to survive as businesses (Field 2010, 179-181). Elite ballrooms were also equipped with facilities for fine dining. These establishments operated kitchens and employed chefs and waiters and they had tables and chairs surrounding the dance floor, which were used by customers and hostesses to dine, drink, and socialise while watching the performers and the dancers. These were social spaces, where people from many different social, occupational, or even socio-economic backgrounds could meet, eat, drink, mix and mingle on and off the dance floor. Whether one's eliteness was expressed through one's culinary tastes, or through the number of champagne bottles one's party 
consumed in the space of an evening, or simply by how one dressed, danced, and behaved and whose company one kept, the high-class ballrooms of Shanghai were spaces for the city's elite residents and visitors to celebrate and show off their wealth, power, status, class, style, fashion, and modernity. In this respect, they were similar in some ways to the VIP clubs that operate in Shanghai and other Chinese cities today ${ }^{4}$. The remainder of this paper divides into five sections, each focusing on one of the aforementioned international array of architects who designed the city's finest ballrooms. Each section relates briefly the background of the architect and provides detailed information about the ballrooms he designed, focusing on their main design features and placing each ballroom in the context of the building that housed it.

\section{Abelardo Lafuente and the Astor House and Majestic Hotel Ballrooms}

In 1913, a Spanish architect named Abelardo Lafuente moved to Shanghai from Manila and settled in China's most modern metropolis for much of the rest of his life and career. The various building projects that he became involved with over the next 15 years included garages, mansions, cinemas, and hotels, but he was best known for his designs of entertainment halls, especially ballrooms (see the article by Álvaro Leonardo Pérez in this issue) ${ }^{5}$. In 1927, a caption that appeared along with a photo of the architect elucidates the wide range of Lafuente's architectural work in the city: 'A Builder of Buildings-Mr. A. Lafuente, the well-known Shanghai architect, who designed the Majestic and Astor House Hotels, the Ritz Building and several banks, cinematographs and garages, is leaving shortly for America, where he plans to build an up-to-date ballroom in connection with a Hollywood concern in Los Angeles' (China Press, April 10, 1927, C4). That he was heading to Hollywood after his long stint in Shanghai is an indication of the high stature he had achieved through his architectural work in this city.

\section{The Astor House Ballroom}

Lafuente's first ballroom design project was for the Astor House in 1917. The Astor House, one of Shanghai's earliest international hostels located north of the Garden Bridge on the Bund, had recently undergone extensive renovations in order to accommodate the growing number of international visitors to the city. While dancing was yet to become a regular pastime in the city, hotels were in competition to attract the city's elites by offering spaces for their leisure and social activities, most notably the seasonal grand balls of the various national communities. These included the American George Washington's Birthday Ball, the British St. George's Day Ball, the Scottish St. Andrew's Day or Caledonian Ball, and many others (Field 2010). Lafuente and his partner G. Wootten were hired by the hotel company to design a new ballroom for the hotel.

The new ballroom opened in late November 1917. As reported in lavish detail in the North China Herald, the city's leading English newspaper, the ballroom featured many alterations including the removal of a wall and its replacement with a passageway reinforced by concrete piers and girders to connect the ballroom to several private rooms. The dance floor measured 95 feet by 70 feet, and the ballroom featured a stage for an orchestra. The floor of the ballroom was made of oak and highly polished for dancing (Figure 1a, Figure 1b). Special attention was paid in this report to the decorations and lighting: 'The mural decorations are tastefully done in cream and white matt paint picked out with old gold; the electric lighting scheme was also well thought out, the result being a pleasing soft effect with ample brilliancy.' (North China Herald, December 1, 1917, 533) The opening of this new ballroom would establish the Astor House as the premier hotel for hosting grand balls and soirees for Shanghai's high society for many years to come. With an additional 2,000 square feet of capacity, including an enlarged dance floor, the new ballroom had twice the capacity of the previous one (Millard's Review of the Far East, September 15, 1917, 79). This was important, since the guest lists for grand balls in Shanghai often numbered in the hundreds and sometimes in the thousands. Even prior to the dawn of the Jazz Age, the ballroom of the Astor House designed by Lafuente was meant to carry guests into a fantasy dreamworld of pleasure and fun enhanced by the electric lighting scheme, the murals, and the polished oak dance floor.

With the arrival of jazz in Shanghai beginning around the end of World War I in 1919, the city's elites took to dancing with more regularity, and a number of other ballrooms arose in Shanghai (Field 2010). In order to continue to be in the forefront of the competition, the Hong Kong and Shanghai Hotel Company, which owned the Astor House, hired Lafuente once more to come up with an even grander and more fantastical design for the ballroom. The Spanish architect did not disappoint them, and the newly renovated and extended ballroom that opened up in 1923 became more popular than ever with Shanghai's high society. As reported in the North China Herald in December 1923, the initial reaction to the design of the 

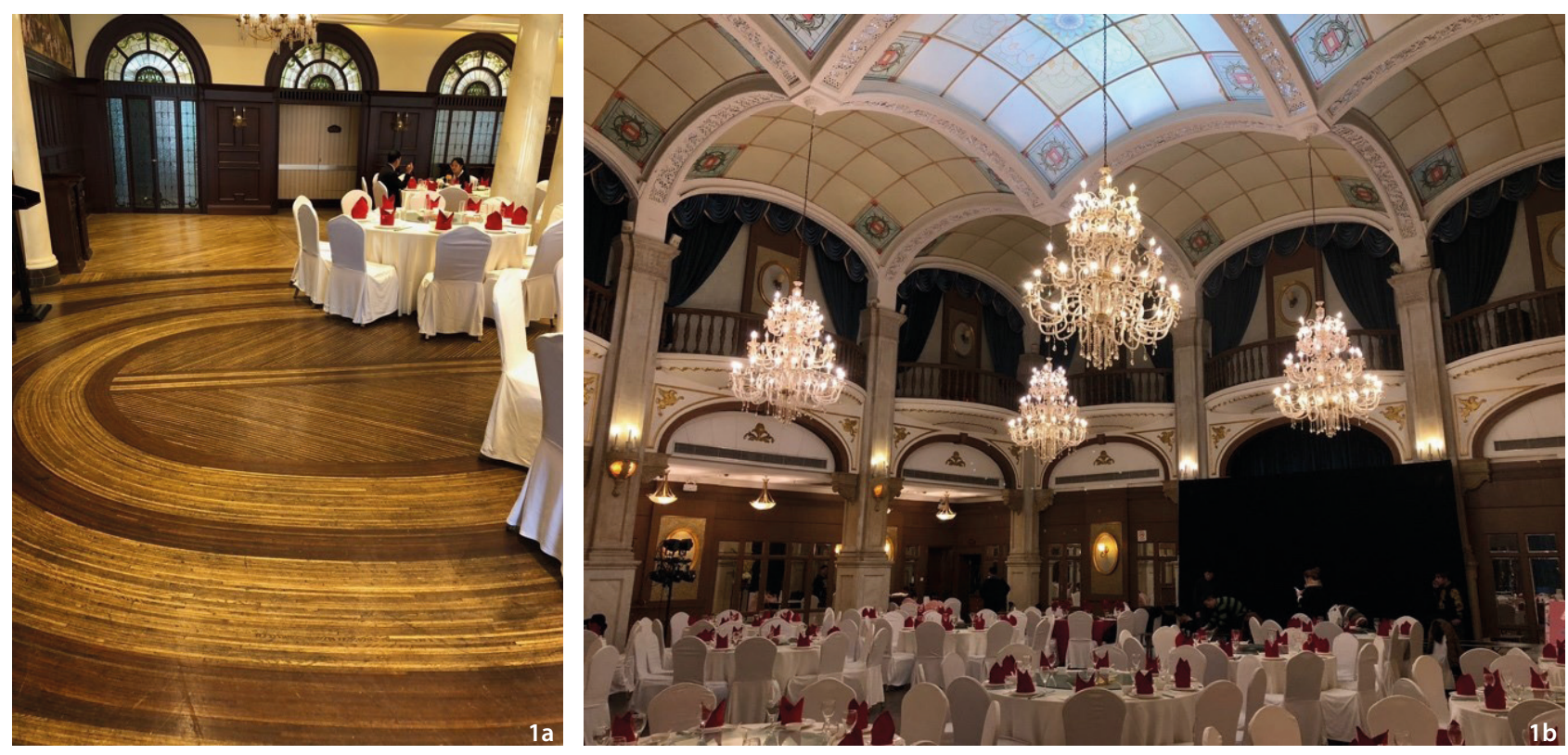

Figure $1 \mathrm{a}$ and Figure $1 \mathrm{~b}$ Photos of the Astor House ballroom showing the original wooden dance floor and the original skylight (the chandeliers are newer additions) (Source: the author).

new ballroom on its opening night was quite positive to say the least, and around 375 guests crowded into the new space to experience it firsthand. 'Those who attended the first night declared that words could not describe the marvellous combination of colours and lights that have been the product of the mind of Mr. A. Lafuente, the designing architect.' (North China Herald, December 29, 1923, 891) Of particular interest to the guests was the orchestral shell designed in the shape of a peacock's fan, which became an iconic feature of the Astor House for many years to come (Figure 2). Not only the design of the peacock shell itself, but more importantly the ingenious way that colours were projected on the shell left customers of the ballroom spellbound. As described by the press, 'Five primary colours have been used for still effects throughout the variegated bedecked panels of feathers, but the revolving cylinder hidden added hundreds of shades of light that blended and dissolved over the whole giving the appearance of running waves of rainbow hues' (North China Herald, December 29, 1923, 891). In addition to murals, carvings and figures featuring mythical merrymakers, the use of multicoloured lights and their enhancement through design features and technologies became a signature aspect of ballroom design throughout this era.

\section{The Majestic Hotel Ballroom}

The same hotel syndicate that ran the Astor House was soon busy setting up a new hotel in the middle of the International Settlement. Located on the corner of Gordon
Road and Bubbling Well Road (now Nanjing West Road) a mile or so to the west of the Race Course and Recreation Ground, the new Majestic Hotel was built out of the former McBain residence. Upon its opening in 1924, it was reputed to be the finest hotel in all of Asia. Its centrepiece was its clover-leaf shaped marble ballroom, which Lafuente designed. As with the Astor House, the design of the Majestic Hotel was meant to convey an atmosphere of opulence, while also connecting the customers to the heritage of Western civilization of which ballroom dancing was a part.

For its opening in 1924, around 800 guests came to marvel at Lafuente's latest creation. As reported in the North China Herald, the new ballroom was a smash hit amongst the city's elites. 'Differing as this room does from the elegance of the Astor House ball-room, the lightness and extreme vivacity expressed in the harmonious unified finish of this one does great credit to the architect, who evolved such a scheme of brilliance, Mr. Lafuente.' (North China Herald, November 1, 1924, 189) The article goes on to describe the clover-leaf shaped ballroom and its many design features, including a fountain in the centre of the room made of marble and bronze, with a mermaid rising from its centre. The ballroom featured ornate statuary with a Renaissance flavour and was designed in a classical style connecting ballroom-goers to Greco-Roman civilisation (Figure 3). As with the Astor House, one remarkable feature of this ballroom was its lighting: 'The cleverly concealed lights, a product of the electrical genius's art, 


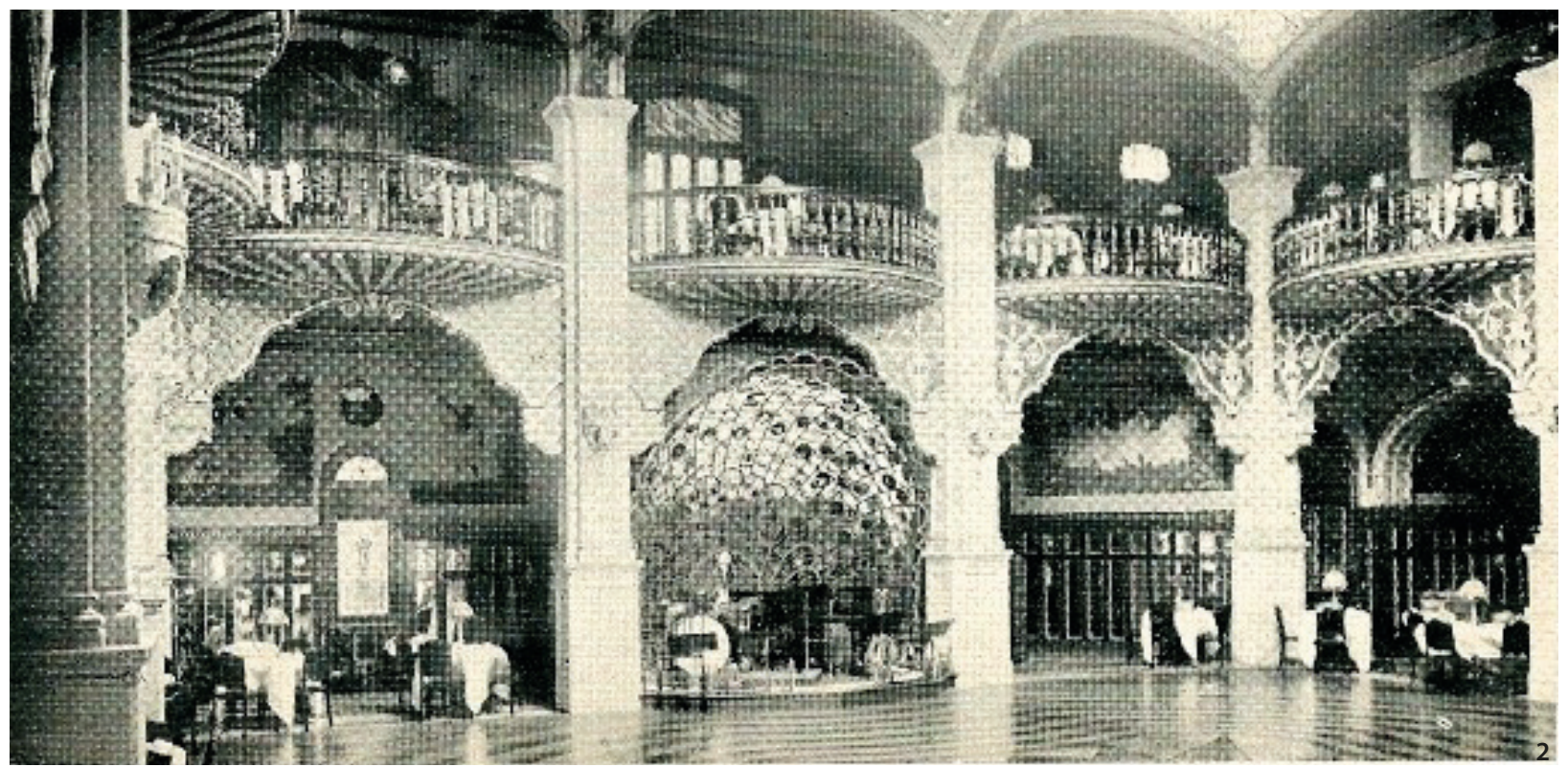

Figure 2 Astor House ballroom (Source: 1932 guidebook on Shanghai).

add to the delightful ensemble effect of the whole in full view of the diners, who surround the floor, sitting on a raised dais, giving each a full view of those swaying to the strains of the former but augmented Astor House [jazz] orchestra, under the direction of Mr. "Whitey" Smith' (North China Herald, November 1, 1924, 189). The dance floor was built on springs, making it easier for the patrons to dance the night away to the tunes of Whitey Smith's jazz orchestra. There were candeled chandeliers and 60 bronze lamps that provided more illumination. The Majestic Hotel ballroom went on to become a favoured rendezvous for Shanghai's elites, eclipsing the Astor House in popularity in the late 1920s as the premier location for grand fetes. Over the next several years, the Majestic Ballroom was used frequently by different communities for large events and festivities including national grand balls, costume balls, charity events and many others (Figure 4).

The most significant historical event that took place in the Majestic ballroom was the wedding of Chiang Kaishek, China's then national leader, to Soong Mei-ling on December 1, 1927. Even more significant for the social and cultural history of the city of Shanghai was the central role the Majestic Ballroom played in introducing jazz music and western social dancing to Chinese elite society. As told by the jazz bandleader Whitey Smith in his memoir and supported by accounts in Chinese newspapers of that period, the Majestic Ballroom was the place where Chinese customers first came in large numbers to dance (Smith 2017 and Field 2010, 47). Its popularity on the eve of the Nationalist Revolution marked a sea change in Chinese urban culture, sparking the dawn of the Chinese Jazz Age which would lead to the establishment of numerous other cabarets or ballroom dance halls in the city in the late 1920s and 1930s. Despite its success with Shanghai's elite society, the Majestic Ballroom ceased to operate in 1931. The hotel was closed down owing to the onset of the Great Depression and the inability of the hotel syndicate to sustain its enormous overhead in hard times. Competition from other hotels that were far more modern in conception and design, such as the Cathay Hotel discussed further on in this paper, may also have contributed to the downfall of this stately Majestic Hotel. Eventually, the building was destroyed. This was certainly a tragic outcome for the built heritage of the city and for the architect who designed its ballroom.

Lafuente, who had moved to Los Angeles to help build some of Hollywood's finest theatres and homes, returned to Shanghai in 1931 to learn that his cherished ballroom, undoubtedly his crowning achievement in Shanghai, was about to be demolished. In two articles published upon his return to Shanghai in October of that year, Lafuente expressed regrets that the Majestic Hotel and Ballroom were being destroyed, and railed at the unpreparedness of the city for its future and the low quality of its buildings, which were not built to last (China Press, October 19, 1931; China Press October 22, 1931). Later that year, he died in a Shanghai hospital from a disease he had contracted while visiting Mexico. One might also surmise that with the impending demolition of his most famous building, the Spanish architect had died of a broken heart. 


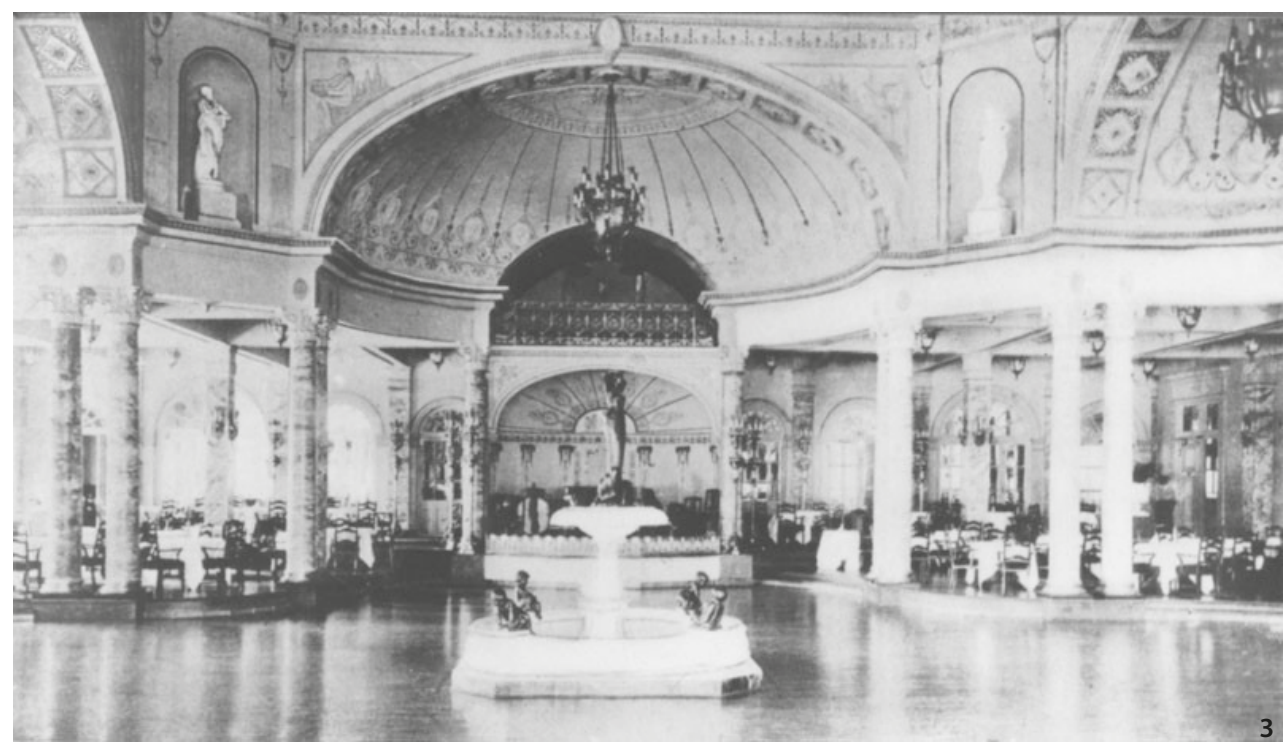

Figure 3 Majestic Ballroom (Source: a collection of photos of Shanghai from the 1930s). Figure 4 Russian Charity Ball and fashion show given at the Majestic Hotel Ballroom (Source: China Press, December 25, 1926).

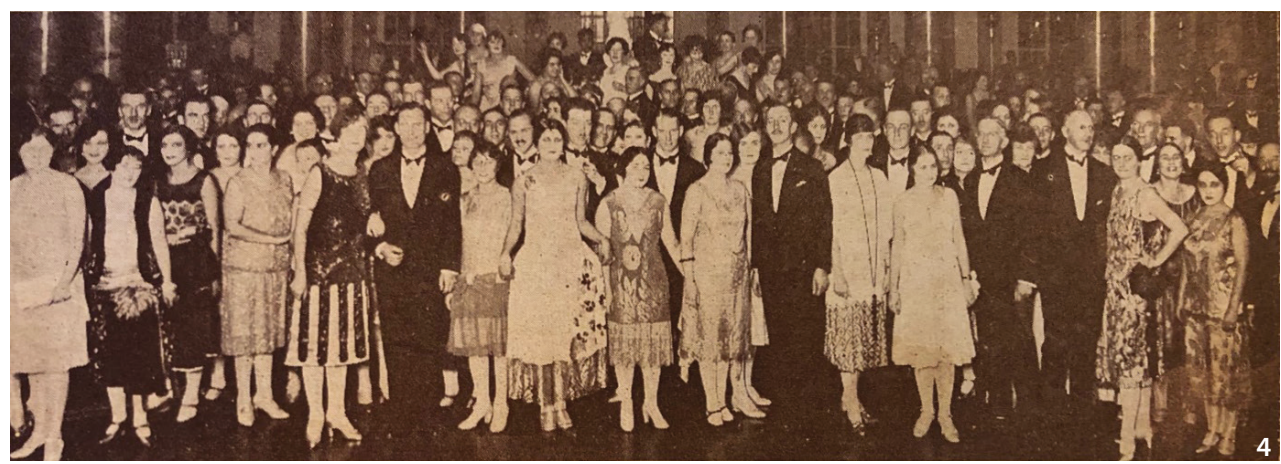

While the destruction of the Majestic Hotel and its ballroom struck a heavy blow against the city's cultural heritage, out of its ashes would rise another ballroom designed by a Chinese architect, who displayed great ingenuity in terms of creating a signature space in the city that 'Sinicized' the western cultures of ballroom dancing and jazz. This was the Metropole Ballroom, which will be covered later in this paper. Meanwhile, a number of other establishments in the city had also hired the city's leading architects to erect fine ballrooms, which if not outshining the splendid magnificence of the Majestic Ballroom, certainly outlasted it.

\section{Paul Veysseyre and the French Club or Cercle Sportif Francais}

At around the same time that the McBain property was being converted into the Majestic Hotel, a French architect named Paul Veysseyre and his partner Leonard were labouring on a commission to design a new building to house the French Club, otherwise known as the Cercle Sportif Français ${ }^{5}$. Veysseyre and Leonard were the designers of dozens of fine homes and public buildings in the city's French Concession, many of which still stand today. Veysseyre had received training in architecture in Paris prior to joining the French Army in World War I. After the war ended, he returned to architecture and in 1921 he took a job in the northern Chinese city of Tianjin. However, he soon decided to settle in Shanghai and in 1922 he started a practice there. Soon afterwards he and his partner were given the commission to build the new French Club which would replace the current club located on Route Vallon (Nanchang Road), which is now the Shanghai Science Hall (shanghai kexue huitang).

The spot chosen for the new location was a large plot of land located on Route Cardinal de Mercier (now South Maoming Road) just north of the most famous road in the French Concession, Avenue Joffre (now Huaihai Road). Veysseyre and Leonard used a combination of more classical designs for the exterior of the building and chose the new Art Deco style as the defining feature for the building's interior (Dodington and Lagrange 2014). The French Club was a private member's only club, which unlike many other clubs in the city was open to all nationalities and to both sexes, making it the most progressive club in the city. When opened in 1926, the new French Club featured a 

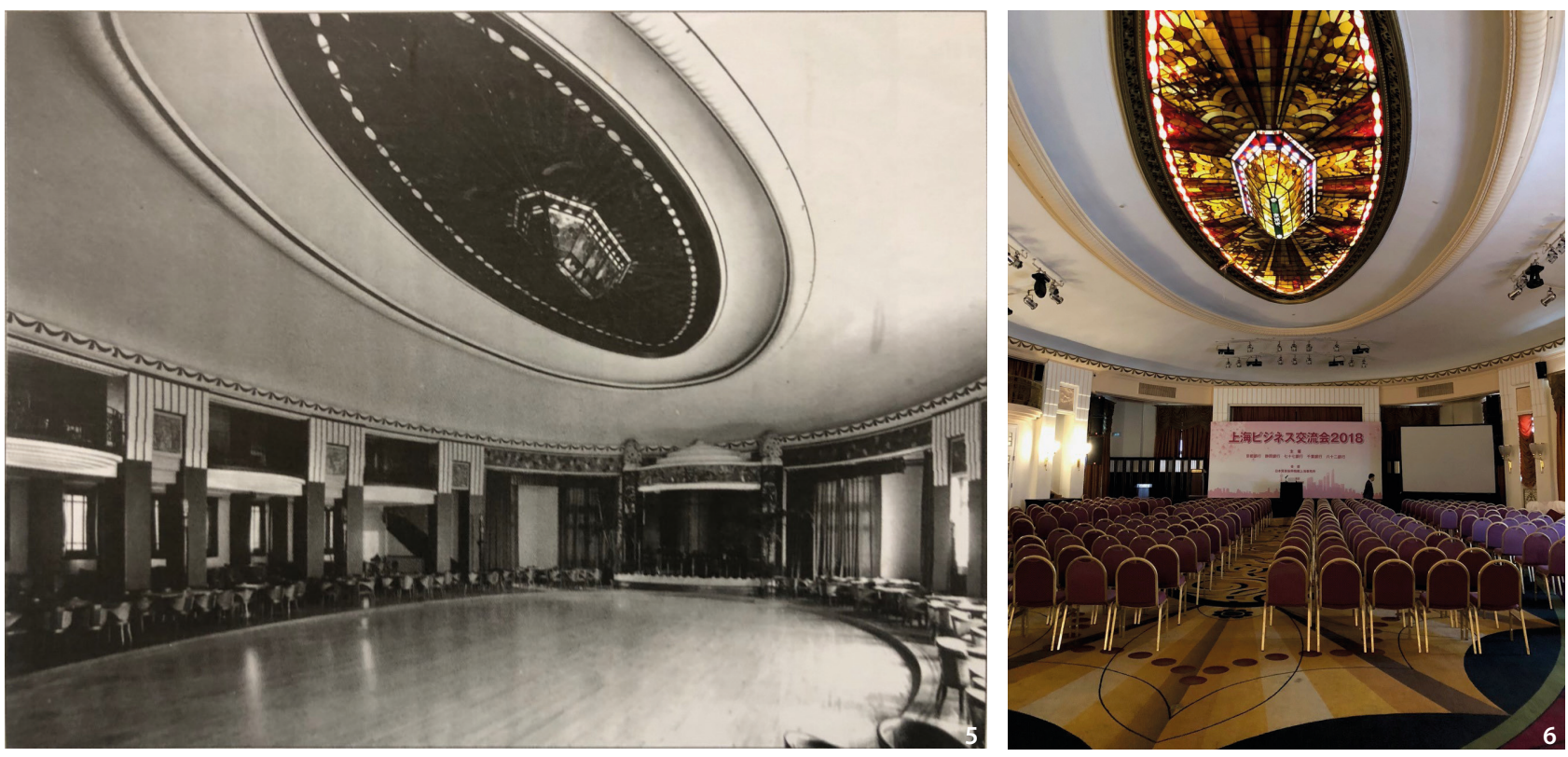

Figure 5 French Club Ballroom in 1920s (Source: Dodington and Lagrange, Shanghai's Art Deco Master).

Figure 6 French Club ballroom (Garden Hotel) in 2018 being prepared for a Japanese business conference in Shanghai (Source: the author).

large swimming pool, a library, a billiard hall, dining halls, a tearoom, and other amenities.

The centrepiece of the new French Club was its ballroom. An article published in the North China Herald called it a 'fitting climax' to the club as a whole (North China Herald, February 6, 1926, 236). The spacious ovalshaped ballroom was fitted with a sprung dance floor made of polished wood. Surrounding the floor were tables for guests to watch the dancing while dining, chatting, and drinking. An orchestral stage was placed at the far end of the oval and was 'flanked by pillars of a most intriguing shade of red. Bas relief decorations above the main entrance door and on the walls of the ballroom depicted idyllic scenes of merrymaking. 'Daring?' concluded the North China Herald. 'Of course it is. Different? That is surely what was intended, and with all its daring and difference it will form a most brilliant setting for many a delightful social function.' One of the key design features of the ballroom was the stained-glass ceiling light fixture, which dominated the central part of the ceiling of the club right above the oval-shaped dance floor, casting a sunburst of oranges, yellows and reds down on the dancers below (Figure 5). According to Dodington and Lagrange (2014), this represents the 'floral style of early French Art Deco'. The ceiling fixture and other decorative elements can still be seen in the ballroom today.

As predicted by the newspaper, after its opening in 1926, the ballroom of the new French Club soon proved to be a choice location for the staging of national balls and other events and festivities by Shanghai society, not only the French community, but many other nationalities as well. Many news articles published in the 1920s and 1930s attest to its popularity, showing various national and international gatherings of people posing for group photos inside the ballroom. The sprung dance floor allowed for more extended dancing, and the ballroom was used regularly for dances as well as staged performances. Decades later, when Mao Zedong launched the new era under the People's Republic of China in 1949, the French Club hosted Chairman Mao in his visits to Shanghai together with official leaders before the construction of the Xijiao State Guest Hotel at Hongqiao Road in the 1960s, as photographs mounted on the walls and corridors in the old French Club today attest. This historical significance was one of the reasons for which the club and ballroom with all of its decadent design-work survived throughout the second half of the $20^{\text {th }}$ century. In 1990, the old building of the French Club was integrated into the Okura Garden Hotel and became the main lobby of the hotel (Figure 6).

\section{George Leopold Wilson and the Cathay Hotel (Peace Hotel) Ballroom}

In the same year that the French Club opened in 1926, construction began on a new hotel located on choice waterfront property at the corner of Nanjing East Road and the Bund. This would become the famed Cathay Hotel and Sassoon Hotel, known since the 1950s as the Peace Hotel $^{6}$. This landmark building on the Bund was financed 
by the British tycoon Sir Victor Sassoon, who invested his family's prodigious wealth in valuable real estate and built some of Shanghai's most enduring monuments to wealth, power, privilege, and luxury. Among them, the Cathay Hotel stands out as one of the great hotels from the age of Art Deco. Today it is still considered a global masterpiece of modernist architecture from that era. Unlike the French Club, the Majestic Hotel, or the Astor House, whose more classical designs were meant to evoke an earlier age of splendid opulence, kindling visions of ancient Greece and Rome, the Cathay Hotel was strikingly modern and drew inspiration from the buildings of midtown Manhattan and the modernist designs of contemporary Europe.

George Leopold Wilson, known by his nickname of 'Tug', was the chief architect of the building. Working since the early 1900s for the Hong Kong based British architectural firm Palmer and Turner, Wilson started the branch office of the firm in Shanghai between 1912 and 1914. In addition to the Cathay Hotel, he was responsible for designing many of the finest and most iconic buildings lining the Bund, including the Hong Kong Shanghai Bank Building (now the Pudong Development Bank), the Customs House, and the Bank of China Building. At first, the Sassoon House was meant to hold offices, but in 1928, Victor Sassoon changed the plans and requested that a luxury hotel be built on the upper floors. This new plan included adding a ballroom for dining and dancing, which was built on the eighth floor of the hotel. In addition to its luxurious Deco features and its Lalique glassworks, the ballroom featured a sprung dance floor, indirect lighting, and air conditioning. It had doors that opened onto a balcony where one could look out at the stunning view of the Bund and Huangpu River below. As reported in the China Press after its opening in 1929, the ballroom had many features that were similar to those of the French Club and Majestic Hotel, including a sprung dance floor made of maple.

As usual, special attention was paid to the design, décor, lighting and colouring of the Cathay Hotel's $8^{\text {th }}$ floor ballroom. 'The colouring scheme of this room is gold silver, rose and mother of pearl and is set off with the wonderful Lalique glass figures, plaques and pendants. The main lighting scheme is by indirect, lighting, with a special arrangement by which the lights can be dimmed gradually or intensified.' (China Press, August 2, 1929) The North China Herald's report on the Cathay Hotel's opening in 1929 emphasised the ballroom's lighting scheme, which was the product of French glassmaker René Lalique (1860-1945): 'After the first glance ... one almost loses interest in everything except the wonderful Lalique lighting, which is a riot of beauty in the dining room [ballroom].' The Lalique lighting fixtures, which are still in the ballroom area today, included ten 'Ladies of the Fountain' placed in niches on the columns, as well as sparrow plaques and lanterns made of moulded glass, and other glassworks illuminated at night, all of which gave an oceanic and other-worldly atmosphere to the ballroom (North China Herald, August 3, 1929, 174). In 1932, the ballroom was remodelled and enlarged and a new air-conditioning system was installed for the comfort of guests who could dance the night away every evening to the tunes of the American bandleader Henry Nathan and his jazz orchestra (North China Herald, August 3, 1929, 178). The ballroom continued to be a nighttime hotspot for tourists and residents alike into the 1940s. When the PRC was established in 1949, the glory days of the hotel came to a sudden end, although the hotel continued to function in its new guise as the Peace Hotel, catering to international visitors from China-friendly countries. Beginning in the 1990s, the hotel underwent a series of renovations, and the $8^{\text {th }}$ floor ballroom was once again used for occasional nighttime dance parties and regular events such as wedding parties (Figure 7). Nonetheless the ballroom did not feature any regular dancing, and it was eclipsed by the Jazz Bar on the ground floor, which since 1980 has featured an 'Old Man's Chinese Jazz Band' playing popular tunes from the 1930 s and 1940s to international tourists.

\section{László Hudec (1893-1958) and the Sky Terrace Ballroom of the Park Hotel}

When the Austro-Hungarian architect László Hudec arrived in Shanghai in 1918 after a daring escape from Siberia where he had been a prisoner of the Russian Army, nobody could have predicted that he would eventually design the tallest and most modern hotel in the city and also its most exclusive ballroom. In addition to the dozens of other buildings that L. E. Hudec and his architectural firms were responsible for designing during his long sojourn in the city from 1918 to 1945, the Park Hotel, financed by a group of Chinese bankers representing the Joint Savings Society of Shanghai, would stand out as one of the most iconic buildings of 1930s Shanghai, and until the 1980s it remained the tallest building in the city, though it is now dwarfed by hundreds of taller buildings erected in the city since the 1990s. Built in the 1930s in a Gothic modernist style that was reminiscent of and certainly inspired by the skyscrapers of midtown Manhattan, and surpassing the Cathay Hotel in many ways, not least 


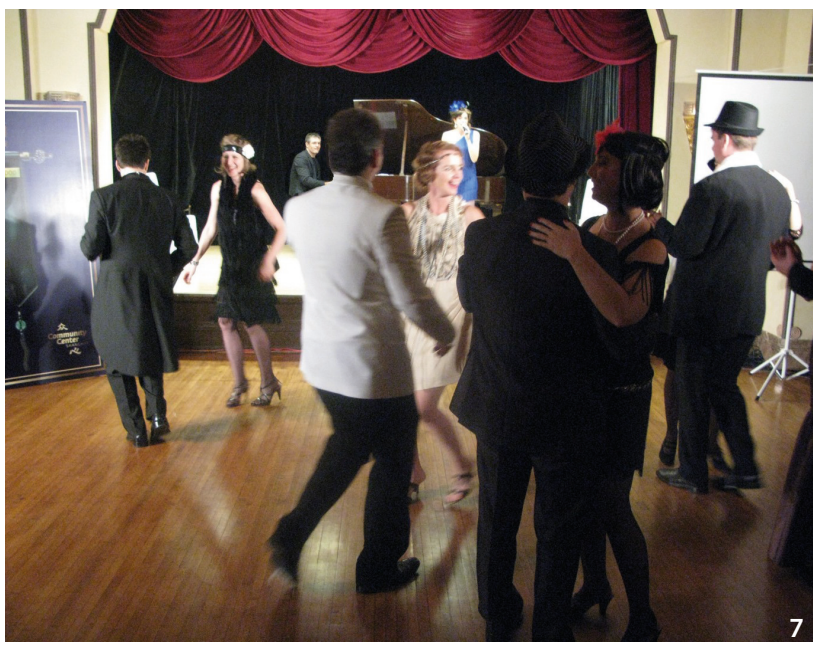

Figure 7 People dressed in 1920s-style outfits dancing at the Peace Hotel Ballroom on the evening of November 20, 2010, with musical accompaniment by American pianist Steve Sweeting and singer Heidi Krenn (Source: the author).

of which was the imposing height of the building at 23 floors, the Park Hotel had a commanding view of the city from its choice position on Nanjing Road overlooking the Recreation Ground of the International Settlement. Not long after it opened in 1934, the $14^{\text {th }}$ floor grill room and rooftop garden was converted into what became one of the key features of the hotel. This was its ballroom, known as the Sky Terrace.

Hudec made sure that the ingenious design of the Park Hotel ballroom reflected the modern elegance of the building that housed it. Indeed, soon after it opened in 1935, the ballroom would attract distinguished members of elite Chinese and western society in Shanghai for years to come. The design of the ballroom took advantage of the lofty height of the building in which it was housed, offering panoramic views of the city in all directions. The ballroom was surrounded by large plate glass windows, which could be slid open to allow the relatively cool breeze to enter the room. There was also a plate glass ceiling, which could be slid open to reveal the stars to nighttime dancers, 'so that guests may find themselves high above the city dining and dancing under cool breezes and-star-lit skies' (China Press, May 25, 1935). At the centre of the ballroom was a fine wooden dance floor designed in floral shape, which is still there today. As with the French Club, Decostyle bas relief figures graced the area near the ceiling, although these were more jazzy, abstract, and musical than the more classical figures of sporting nymphs and revelers of the French Club.

As with other luxury ballrooms in the city, special colouring and lighting features were also used to create an otherworldly atmosphere for the Sky Terrace ballroom of the Park Hotel. According to the China Press report in 1935, 'Modern lighting installations will be introduced and these will serve to heighten the effect at night. For the most part lighting will be indirect, but spotlights and a large revolving mirror light will also be used on occasion.' The same report noted that Hudec had put considerable thought into the design of the terrace: 'Formerly the terrace was an open one, but it was later decided to enclose it and afford guests the advantages of protection without its disadvantages' (China Press, July 28, 1935). Thus, in all seasons and all types of weather, the ballroom of the Park Hotel could be used by Chinese and western elites to dine, drink, and dance the night away. Frequent guests included the Chinese Mayor of Shanghai Wu Te-chen (We Tiecheng), as well as other dignitaries, businesspeople, and officials from many different nations.

Ruth Day, a visitor to the city from Springfield Massachusetts in 1935, was one eye-witness to the ballroom's charms. Upon her arrival in the city in March 1935, her parents held a welcome party for her in the Sky Terrace ballroom (China Press, March 19, 1935). Her step-father, Dr. Frederick Cleveland, a noted American economist and finance expert and a professor at Boston University, had been invited to China in 1928 to assist the new national government in solidifying its finances. In her book Shanghai 1935 (1936), Mrs. Day describes meeting many of the city's most prominent civic and government leaders during this cocktail party, and she offers a lovely if somewhat orientalist description of the ballroom itself, noting the pillars of the ballroom, which in her account were 'Chinese red with gold scroll-like designs' (Day 1935, 12). Looking down on the city from the 14th floor windows, Day contrasted the civilized and well-lit International Settlement and French Concession with the 'shadowy and sinister' native section of the former walled city of Shanghai beyond. This can be construed as a product of attitudes that prevailed in the age. Still, one must note that the ballroom was financed by Chinese bankers and chiefly serving as a stage for Chinese elites who were contributing to the building of a modern Chinese nation. These people now could literally look down upon the other ballrooms and entertainment halls in the surrounding areas.

\section{Yang Xiliu and the Paramount and Metropole Ballrooms}

While most of Shanghai's elite ballrooms were designed by western architects, one must also recognise the stunning contributions of the Chinese architect Yang Xiliu, 
known by his Anglicized name of S. J. Young. Educated at Jiaotong University in Shanghai, this promising young architect was chosen by the group of Chinese investors who financed the building of the Paramount Ballroom, an elite dance palace and hotel built on Yuyuan Road across from the Jing'an Temple. He then went on to design one of the most unique ballrooms in Shanghai, if not in the world at the time: The Metropole Gardens Ballroom. This ballroom drew upon more traditional Chinese stylistic elements to create a daring architectural synthesis of Chinese tradition and global modernity.

\section{The Paramount Ballroom}

The bankers who financed the building of the Paramount Ballroom in the early 1930s were no doubt making a powerful statement that the Chinese people could finance, design, and build a ballroom that was even more modern, sophisticated, and elegant than those created by the Europeans. To this day, the Paramount Ballroom remains the most well-known and celebrated among the iconic ballrooms of the city's legendary heyday, even if the ballroom itself has undergone many renovations and transformations since it was first built in the early 1930s. Designed by S. J. Young in ultra-modern Deco style, the Paramount Ballroom outshone its counterparts in terms of the intricate and sophisticated design-work both of its exterior façade and interior features (Figure 8, Figure 9).

The publication of an article on the Paramount Ballroom in The Chinese Architect (Zhongguo jianzhu) enables us to peer into the mind of the ballroom's designer Mr. S. J. Young ${ }^{7}$. In this article, Young emphasises six aspects of the building's design that had to be thought out very carefully and strategically through draft after draft. These include: (1) the physical location of the building and its main entrance vis-à-vis the road; (2) the internal arrangement of the building and the layout of the three floors; (3) the design of the ballroom and human traffic flow within the ballroom; (4) the physical construction of the structure of the building; (5) the mechanical equipment inside the building; (6) the selection of materials for the ballroom and building. Among these six sections, the most important for our purposes is section three, which lays out the architect's philosophy for the ballroom's design, comparing it with others in the city, in particular the ill-fated Majestic Hotel Ballroom. In addition to the careful thought that went into this elaborate entertainment space, it may also be conjectured that as a Chinese architect, S. J. Young possessed certain insights into the norms and practices of Chinese social behaviour that may not have been so apparent to the
European architects, who built the other elite ballrooms in the city, and that he was able to apply these insights into the design of the ballroom. Young notes in the article that earlier ballrooms with their cavernous spaces were fine for large parties but did not work well for nights when crowds were small. The large voluminous empty space of a ballroom gave people a feeling of loneliness on regular nights when guests were few. The architect goes on in this article to relate how by creating a set of smaller spaces within the larger framework of the ballroom, he was able to design a ballroom in which both large and small groups of people can feel a sense of enjoyment. As the crowds grew larger, rooms and spaces in the upper floor would be filled, reaching a total capacity of 800 or more, but even with a small crowd on a weekday occupying the main floor, the ballroom could still feel lively. Thus, by creating several different spaces within the ballroom, S. J. Young's design anticipated those of more modern and contemporary clubs that divide the club space into smaller spaces so that guests can feel a sense of crowdedness no matter how many people are present on a given night. The prescient design of S. J. Young's Paramount Ballroom therefore anticipated dance clubs in Shanghai that would not appear in the city for another 70 years or more.

After its opening in December 1933, the Paramount Ballroom became instantly popular with both Chinese and Western customers and remained so for the next two decades. Certainly, the two dance floors were the most celebrated features of this ballroom, although accounts often mentioned the lighting features and the modern look and feel of both the exterior and interior of the building. The China Press described the ballroom soon after it opened to the public. It noted the grand marble exterior and the two dance floors with the main floor laid upon a 'floating-spring bed.' It paid particular attention to the small upper dance floor: 'The smaller dancing floor is an innovation to the Far East. It is of milky crystal from under which glow soft rainbow lights.' Other features of note included the chrome-plated grill-work, a cocktail bar and separate banquet rooms on the upper floor separated from the main hall by sound-proof drapes imported from Vienna (China Press, November 12, 1933). The receptions and perceptions of the ballroom by Western and Chinese customers mirrored the intentions of the Chinese architect S. J. Young. His inclusion of the bar on the edge of the main ballroom and two semi-private banquet rooms on the upper floor with easy access to the smaller dance floor were ingenious additions, which presaged the popularity of VIP bar lounges and privately booked rooms or 

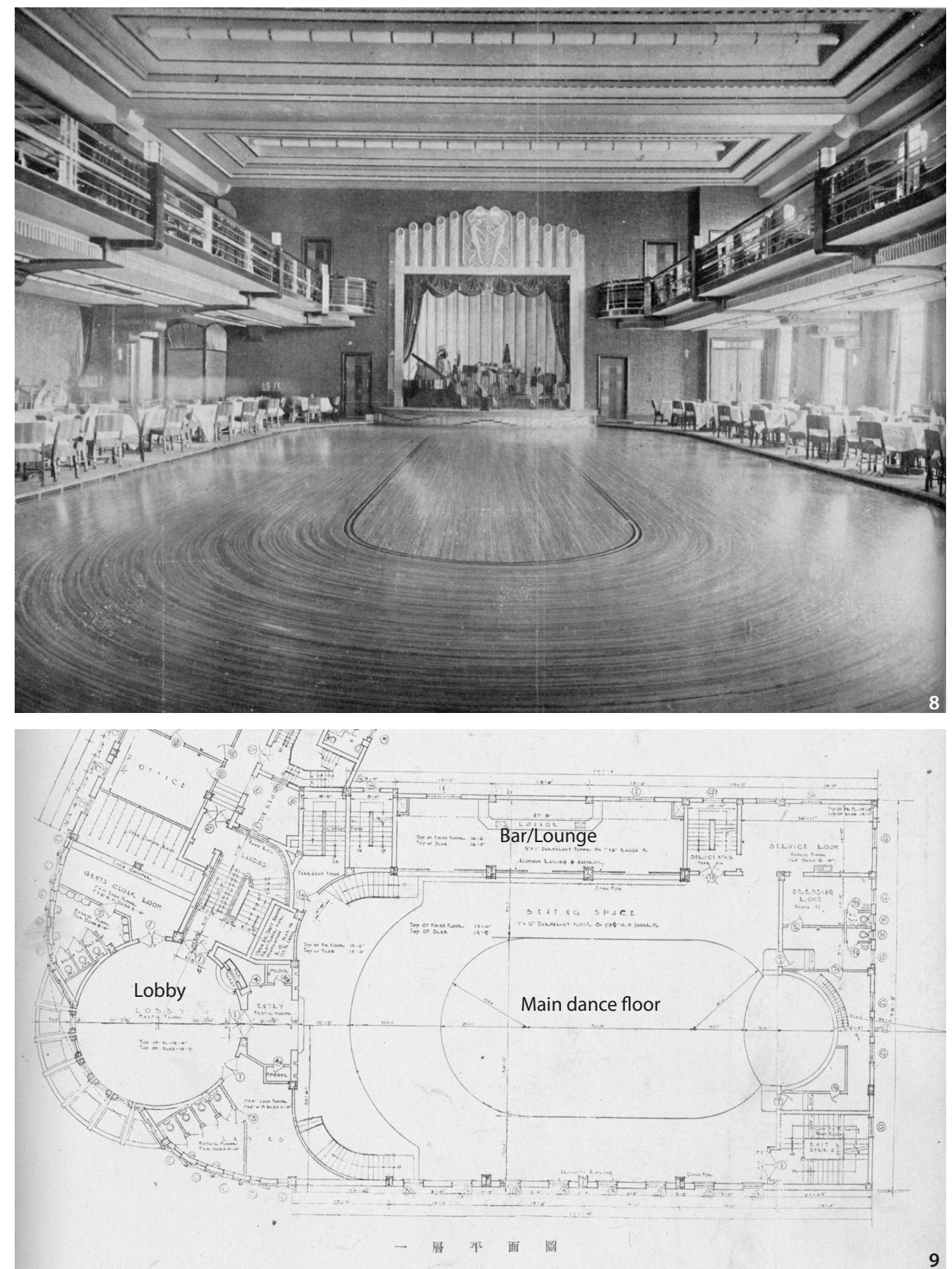

Figure 8 The main dance floor of the Paramount Ballroom (Source: Zhongguo Jianzhu 1934).

Figure 9 Blueprint of the first floor of the Paramount Ballroom (Source: Zhongguo Jianzhu 9 1934).

baofang in swanky Shanghai nightclubs such as Park 97 and Muse in the 2000s (Farrer and Field 2015; Field 2008). One could even argue that a Chinese style of clubbing was emerging in the 1930s as exemplified by the Paramount Ballroom. However, it would take another ballroom, the Metropole, to prove to the Shanghai public that western ballroom dancing and Jazz Age culture could be just as Chinese as Chinese opera and teahouses.

\section{The Metropole Gardens Ballroom}

Built in 1935 in a short span of a few months on the same location where the Majestic Hotel had stood only four years before, the Metropole Ballroom was S. J. Young's crowning achievement in dance palace design, and can be considered one of the most unique ballrooms of the interwar period in the world. This building assignment differed remarkably from his previous one in many ways. First, the budget was far more modest than that for the Paramount Ballroom. Second, the mandate was for a ballroom that would connect to traditional Chinese culture in important ways. Third, and related to the first two, the primary building material was wood. Once again, S. J. Young came up with an ingenious design for the ballroom, which made it quite unique in the history of ballrooms in Shanghai. 


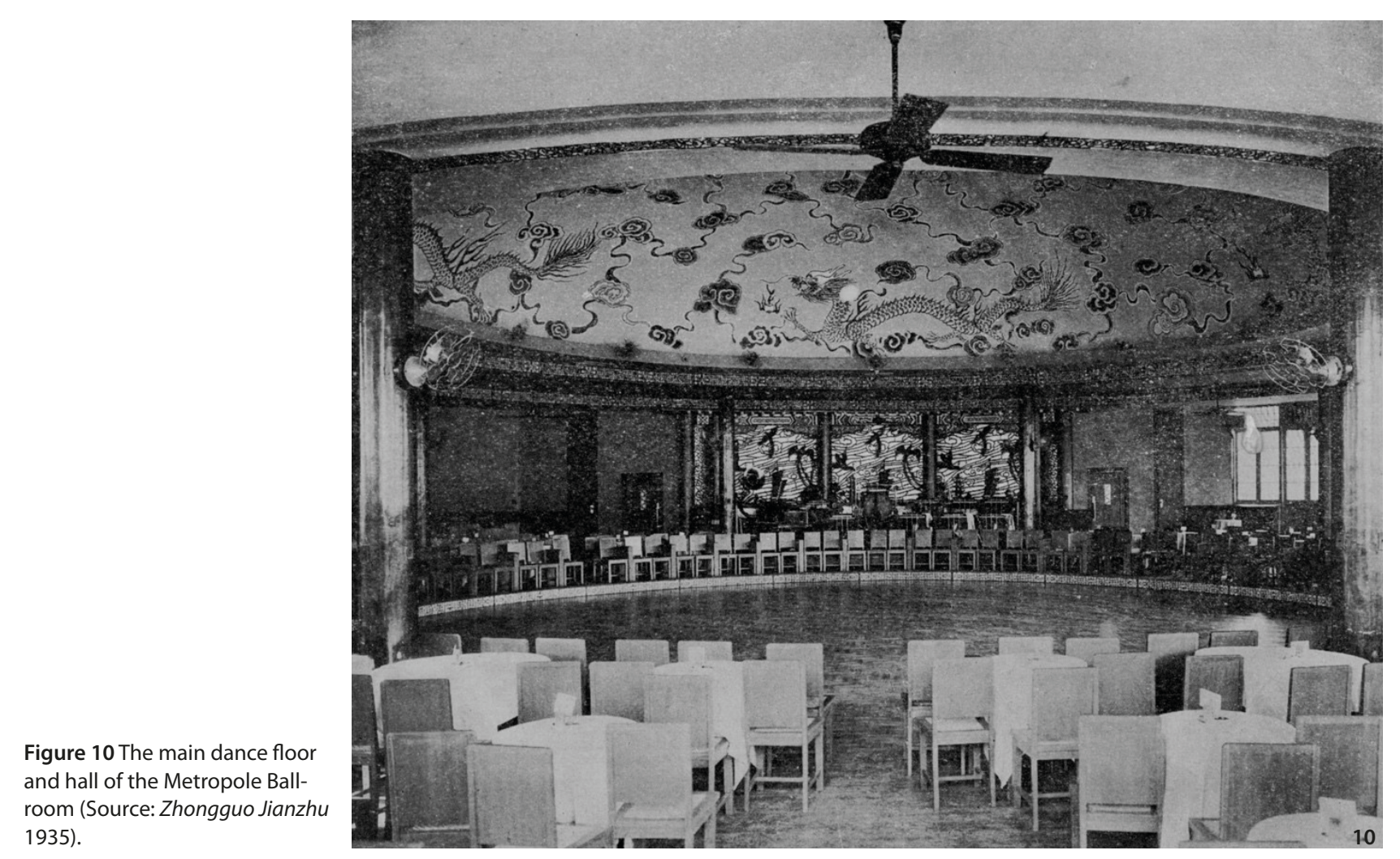

Young's solution to building a ballroom that would not have such a large overhead and which could withstand the vicissitudes of both national and global economic and political crises was to use ready-made materials to design a Chinese-style building reminiscent of a temple or palace from ancient times (Figure 10). One could even call the resulting building Chinese Deco style, since it masterfully combined modern and traditional design elements into a fusion. As with the Paramount, much attention was lavished on the design details of the ballroom. A foyer or entrance hall with a Chinese lantern hanging from the ceiling led into a lounge area, which was octagonal in shape and whose ceiling had Daoist design elements. The main hall of the ballroom featured a circular dance floor topped by a circular dome around which ran painted dragons, while silhouettes of phoenixes rose from behind the orchestral stage. Surrounding the dance floor were tables and chairs for people to dine, drink, and socialize, and there was also an outdoor dance garden for summer months. Instead of air conditioning, the ballroom featured electric fans for cooling guests in the hot summers. The ballroom's design thus conformed to the Nationalist government's dictum to the Chinese people at the time to be economical and use domestically produced materials, and it visually and artistically connected the ballroom experience to traditional Chinese culture, even if this was what we might call today a Disneyfied version of that culture. As for the decision to create a ballroom on the model of a traditional Chinese palace, this was a risky decision but one that panned out nonetheless (Fei 1935).

The primary customer base for this ballroom was arguably the Chinese-after all, one of its financiers was the Green Gang boss Du Yuesheng, and the ballroom featured Chinese dance hostesses. Nevertheless, the ballroom was of course promoted to westerners as well. Upon its opening in August 1935, the China Press published a glowing article about this new ballroom, noting its presence on the very spot where Chinese society had first learned to dance to the tunes of Whitey Smith's Majestic Hotel orchestra. Comparing the ballroom to the famed Temple of Heaven (Tiantan) in Peking, the article gushed: 'The architect, Mr. S. J. Young; who came into prominence with the erection of the Paramount Hotel and Ballroom, considered one of the finest structures of its kind in Shanghai, has given much time and thought to the adaptation of Chinese designs to modern use. If he showed his talent in the Paramount, he has most certainly brought another building to the city which will evoke favourable comment' (China Press, August 10,1935). The article also remarked on the 'cozy' atmosphere of the ballroom's interior and the 'dull gold tints' that 'glow softly' on the walls of the ballroom. A lighted fountain placed in the centre of the marble dance 
floor located in the outdoor garden brought back fond memories of the Majestic Ballroom during its heyday in the previous decade.

\section{Conclusion: Preserving the Cultural Heritage of Interwar Era Shanghai Ballrooms}

For a city that was once world famous for its nightlife, relatively few traces of the jazz-age cultural environment of 1930s Shanghai remain in the city today. Unlike other world cities such as London, New York, and Paris, in which jazz-age entertainment halls continued to be used for similar entertainment purposes, even if the cultures of music and dancing changed over time, Shanghai experienced a huge disjuncture following the end of World War II. After 1949 the dawn of the new age under the leadership of the Communist Party witnessed the departure of most remaining foreigners in the city and the demise of its ballroom and dance hall culture. Most dance halls were converted to other uses in the early 1950s, and public dancing and nightlife disappeared in Shanghai by the end of the 1950s. When dancing was finally revived as a public pastime in the reform era of the 1980s, it was part of a working-class Shanghainese culture and the spaces of dancing were generally modest. The 1990s gave rise to a new era of nightlife with large discos taking the place of social dance halls among the city's youths. The 2000s saw more sophisticated VIP lounge clubs and bars take the place of the discos. Although public interest in the city's 'golden era' and its nightlife has revived since the 1990s, few if any nightlife spaces from the actual Jazz Age were left standing in the wake of the huge building spree that began in that era. Moreover, the actual memories of these spaces and cultures had long since been forgotten in the wake of the social change that characterised the Mao years.

Among the many dozens of ballrooms built in Shanghai in the 1920s and 1930s, most of them have long since disappeared. Yet among the elite ballrooms covered in this paper, several are still in use today. This alone is a testament to the high quality of the work that went into designing and building these spaces as well as their precious role in the archiving of the city's submerged memories as a global crossroads in the pre-Liberation era. Surviving ballrooms from the interwar era include the Paramount Ballroom, the Sky Terrace of the Park Hotel, the French Club (now part of the Okura Garden Hotel), the Astor House, and the Cathay (Peace) Hotel ballroom. All of these ballrooms are ostensibly open to the public and can be visited and used by people in the city today. It should be noted that all of these ballrooms were built into large buildings that mainly functioned as hotels, except perhaps in the case the Paramount, in which the hotel function was ancillary to the ballroom itself (the French Club did not start out as a hotel but ended up as part of one). As for the ballrooms that have survived intact throughout the $20^{\text {th }}$ century, mostly they are now being used for other purposes than social dancing. These spaces are now rented by private and public interests for holding wedding parties, fashion shows, fancy dinner parties, conferences and meetings, and numerous other events.

Among these old ballrooms, only the Paramount Ballroom is still used primarily for its original purpose of social dancing. Soon after the revolution of 1949, the Paramount Ballroom on Yuyuan Road was converted into a movie theatre in the 1950s, gutting some of its original interior in the process. In the 2000s, a Taiwanese investor bought the Paramount Ballroom and converted it back into an actual ballroom in order to cater to the growing nostalgia for the 1920s and 1930s era (actually, there were two spaces: a ballroom for dancing on the top floor and a disco club on the lower floor). Since then, the ballroom has offered 'dance instructors' (wushi) to accompany mostly middle-aged customers of both sexes. Many dance parties have been held in this space in recent years, from swing-dance revivals by groups of Chinese and western expatriates, to old-style ballroom dancing parties led by people such as Qian Xiangqing, one of the legendary revivalists of social dancing in the city since the $1980 \mathrm{~s}^{9}$. Nevertheless, while some of the fundamental design features of the Paramount Ballroom are still intact, the original dance floors and the elegant interior designs, decorations and lighting schemes that originally graced this ballroom are long gone. Despite the availability of original photographs, floor plans and blueprints, little effort has been expended to recover the original Deco style and elegance of the ballroom's interior during its heyday in the 1930s, and many of the original design features, from the main sprung dance floor to the upper dance floor built on plate glass, the cocktail bar, and the private dining rooms were destroyed long ago. The case of the Paramount Ballroom is thus a sad reminder of both the lack of interest and know-how in recovering period design work and attention to detail in Shanghai's heritage buildings in favour of commercial repurposing to cater to general nostalgia.

Other ballrooms have survived the enormous changes in the built environment largely intact. One example is the 
Astor House, otherwise known as the Pujiang Hotel north of Garden Bridge on the Bund. In the 1990s, the groundfloor ballroom was converted into the city's first stock exchange since the 1940s. It was eventually converted back into a ballroom and banquet hall when the stock exchange moved across the river to the Pudong side. The original wooden dance floor built in the 1920s still may be found in the ballroom today, and some of its original design features were still intact in the 2000s, although the famed peacock orchestral shell had long since disappeared. In 2018, the Astor House was converted into a museum for the stock exchange and lost its function as a hotel entirely.

The Peace Hotel (formerly the Cathay Hotel and Sassoon House) has also undergone many extensive renovations over the years. Most recently, it was taken over by the Fairmont Hotel Group, which spent several years from 2007-2010 renovating the entire hotel in order to recapture some of the lost glory and splendour of the original hotel from the 1930s. The $8^{\text {th }}$ floor ballroom did not need a great deal of work, since most of its original design features had been well-preserved over the decades.

As for the old French Club, after being incorporated into the Okura Garden Hotel in the 1990s, its ballroom was repurposed for banquets and private parties. While the wooden dance floors of the Cathay (Peace) and Astor House ballrooms can still be used for dancing, that of the French Club cannot, since a thick red carpet covers the floor and has done so since it became part of the Garden Hotel. While many original design features, such as the bas relief decorations and the stained-glass ceiling fixture are still there, the ballroom lacks the original pizzazz it had in the 1920s and 1930s. As for the Park Hotel's Sky Terrace ballroom, it is used mainly for private dinner parties and wedding parties, and the ingenious design-work of the architect Hudec is no longer apparent, though some of the Deco reliefs are still there below the ceiling. To be sure, the original purpose of these ballrooms as spaces for the city's elites to celebrate their togetherness and class identity through key events such as weddings, dinner parties, and other ceremonial gatherings in these old ballrooms is being revived in the city today, although dancing is no longer central to the rituals of eliteness in Shanghai nor in other world cities.

While these ballrooms housed in landmark hotels and buildings have lasted into the $21^{\text {st }}$ century, many of their original features and designs have disappeared or else been covered up. Meanwhile, many others among the city's finest ballrooms from that era failed to survive the vicissitudes of the $20^{\text {th }}$ century. As discussed earlier, the Majestic Hotel and its famed ballroom were destroyed in the early 1930 s.
The Metropole Gardens Ballroom, which later stood on the same ground as the Majestic Hotel, was also destroyed in the 1990s in the wake of the city's first big building spree since the 1930s. By the late 1990s, a shopping mall called Westgate Mall (Meilongzhen guangchang) arose in its place and is still there today on the corner of Jiangning Road and Nanjing West Road. For a while in the late 1990s, when social dancing was again in vogue amongst the city's working classes, on an upper floor of the shopping mall was a makeshift social dance hall with a circular floor that also called itself the Metropole (daduhui wuting). It was eventually replaced by the visa office of the U.S. Consulate in Shanghai.

\section{Notes}

1. In the Chinese language, these establishments were usually known either as wuting 舞厅 or wuchang 舞场. In the English language, they could be variously known as cabarets, nightclubs, ballrooms, cafes, or dance halls. For simplicity's sake, and because that is what they were usually called when referring to elite establishments, I will refer to them in this paper as ballrooms.

2. The term 'action environment' was first used by the American sociologist Erving Goffman and later taken up by Lewis Erenberg (1981) in his study of the nightlife of New York City in the early $20^{\text {th }}$ century. For an explanation of this term and its application to the space of the cabaret or nightclub see Erenberg, Lewis Steppin' Out: New York Nightlife and the Transformation of American Culture, 1890-1930 (Chicago: University of Chicago Press, 1981) pp. 132-133.

3. Classic studies of American nightlife from the 1920s1930s period include Lewis Erenberg, Steppin' Out: New York Nightlife and the Transformation of American Culture, 1890-1930 and Paul Cressey, The Taxi-Dance Hall: A Sociological Study in Commercialized Recreation (Chicago: University of Chicago Press, 1931; reprinted in 2008).

4. See Andrew David Field and James Farrer, 'China's Party Kings: Shanghai Club Cultures and Status Consumption, 1920s-2010s' in Dorothy J. Solinger, ed., Polarized Cities: Portraits of Rich and Poor in Urban China (Rowman \& Littlefield, 2018). One key difference to the scene today is that ballroom-going elite society showed off its status in the city's newspapers and magazines, whereas overspending in VIP clubs today is largely a private matter, restricted to the clubs, and only tends to surface in the social media on special occasions.

5. For a detailed study of the architect Veysseyre and his legacy in Shanghai, including the French Club, see Spencer Dodington and Charles Lagrange, Shanghai's 
Art Deco Master: Paul Veysseyre's Architecture in the French Concession (Hong Kong: Earnshaw Books, 2014).

6. For a more detailed and comprehensive history of the Peace Hotel or Cathay Hotel and Sassoon House, see Peter Hibbard, Peace at the Cathay (Hong Kong: Earnshaw Books, 2013).

7. Zhongguo jianzhu ('the Chinese Architect') 1934 vol. 2 no. 1 pp. $1-34$.

8. We trace all of these changes in the city's nightlife in fine detail in Farrer and Field, Shanghai Nightscapes.

9. We tell the story of Qian Xiangqing through an interview with him. See Farrer and Field, Shanghai Nightscapes, pp. 39-40.

\section{References}

Cressey, Paul. (1931) 2008. The Taxi-Dance Hall: A Sociological Study in Commercialized Recreation. Reprint, Chicago: University of Chicago Press.

Day, Ruth. 1936. Shanghai 1935. Claremont CA: Saunders Studio Press.

Dodington, Spencer, and Charles Lagrange. 2014. Shanghai's Art Deco Master: Paul Veysseyre's Architecture in the French Concession. Hong Kong: Earnshaw Books.

Erenberg, Lewis A. 1981. Steppin'Out: New York Nightlife and the Transformation of American Culture. University of Chicago Press.

Farrer, James, and Andrew Field. 2015. Shanghai Nightscapes: A Nocturnal Biography of a Global City. Chicago, IL: University of Chicago Press.

Fei, Huo. 1935. "Daduhui huayuan wuting." [The Metropole Gardens Ballroom.] Zhongguo Jianzhu [The Chinese Architect], Sept.: 18-30.

Field, Andrew David, and James, Farrer. 2018. "China's Party Kings: Shanghai Club Cultures and Status Consumption, 1920s-2010s." In Polarized Cities: Portraits of Rich and Poor in Urban China, edited by Dorothy J. Solinger, 127-148. Lanham, MD: Rowman \& Littlefield.

Field, Andrew. 2008. "From D.D’s to Y.Y. to Park 97 to Muse: Dance Club Spaces and the Construction of Class in Shanghai, 1997-2007.” China: An International Journal 6 (1): 18-43.

Field, Andrew. 2010. Shanghai's Dancing World: Cabaret Culture and Urban Politics, 1919-1954. Hong Kong: Chinese University Press.

French, Hilary. 2015. "Glamorous Spaces: Public Ballrooms and Dance Halls, 1890-1950." Interiors 6 (1): $41-57$.
Hibbard, Peter. 2013. Peace at the Cathay. Hong Kong: Earnshaw Books.

Mumford, Kevin. 1997. Interzones: Black/White Sex Districts in Chicago and New York in the Early Twentieth Century. New York: Columbia University Press.

Nott, James. 2015. Going to the Palais: A Social and Cultural History of Dancing and Dance Halls in Britain, 1918-1960. New York: Oxford University Press.

Nott, James. 2018. "Dance Halls: Towards and Architectural and Spatial History, c. 1918-65." Architectural History 61: 205-233.

Smith, Whitey. (1958) 2017. I Didn't Make a Million: How Jazz Came to China. Reprint, Hong Kong: Earnshaw Books. 